\title{
Profitability and Capital Structure: An Empirical Study of French and Hungarian Wine Producers in 2004-2013
}

\author{
Martin Luptak \\ Bureau Van Dijk, Slovak Republic \\ Daniel Boda \\ Szent Istvan University, Hungary \\ Gabor Szucs \\ Creditreform Hungary, Hungary
}

\section{Abstract}

Background: Profitability of the Hungarian wine industry has been a focus of numerous research studies due to the centuries-old history and the recent changes. Objectives: The aim of the study is to analyse the capital structure of the Hungarian and the French wine industries and demonstrate the benefits of the usage of an international company database. Methods/Approach: First, the database and the applied methods are described and then the descriptive statistical analysis of the industry is presented. The two set hypotheses are aimed at testing the main contradiction between the pecking order and the trade-off theory, which is related to profitability and the usage of external funds. Results: The analysis examines the differences between the funding policies applied in the two countries. This was carried out by means of a discriminant analysis, which indicates the financing characteristics of French and Hungarian wine producers. In order to confirm the results of the discriminant analysis we conducted a cluster analysis on the same sample where 3 out of 4 variables proved to be significant in classifying the two groups. Conclusions: The main conclusion of the study is that the behaviour of the factors explaining the development of the capital structure differs significantly in the two examined countries.

Keywords: capital structure; discriminant analysis; profitability; Hungary; France; wine JEL classification: G32, C30

Paper type: Research article

Received: Nov 8, 2015

Accepted: Feb 5, 2016

Citation: Luptak, M., Boda, D., Szucs, G. (2016), "Profitability and Capital Structure: An Empirical Study of French and Hungarian Wine Producers in 2004-2013", Business Systems Research, Vol. 7, No. 1, pp. 89-103.

DOI: 10.1515/bsrj-2016-0007 


\section{Introduction}

The development of the Hungarian wine industry has always been followed with great attention considering its centuries-old history and the recent changes. However, it has been difficult to assess how the players have responded to the privatization and to the challenges of accession to the EU. Therefore, our aim is to present an examination not only of the capital structure, but also of the performance of the sector. By comparison, the French wine industry was involved in the analysis as well, as it is one of the largest markets, and has both great traditions and a global reputation. The aim of the study is to find those variables that distinguish the two industries from each other. According to our hypothesis the French industry, which has a higher reputation and a greater market share, will also have better profitability, which in turn, affects the accessibility to external funds in a positive way.

Previous studies have not been very decisive regarding this topic, since in most of the cases, they have indicated that the financing from the industry's own capital has proved to be a greater determinant. In the French wine industry, Viviani (2008) found a negative, significant connection between the profitability and the capital structure. In the examined sample, there were both SMEs and large companies, and the examination covered the period from 2000 to 2003. Based on Margaritis and Psillaki (2008), higher leverage is related to improved efficiency with positive significance level but only at low to mid-leverage. Gill, Biger and Mathur (2011) found positive correlation between capital structure and profitability on a sample of 272 American firms listed on the New York Stock Exchange for a period from 20052007. Xu's (2012) results were also consistent with the trade-off model that predicts positive relation between the two examined variables. Psillakia and Daskalakis (2009) found positive relation between leverage and size as opposed to the connection of asset structure and leverage. Profitability is also negatively related to leverage and as expected, negative correlation can be seen between leverage and risk, i.e. the riskier the operating company, the less debt burden is expected to implement. From among the main trends, the traditional theory (Modigliani \& Miller, 1963; Stiglitz, 1972) claims that the gearing can have a positive influence on the profitability; the higher the profit of the company, the greater intention they have to apply for a loan, as in this case, they can benefit from the tax shield. The same is true on the investor side, since the more profitable companies are more likely to get a loan. The agency theory confirms the higher leverage hypothesis as a disciplining tool against the management (Jensen \& Meckling, 1976). However, according to the pecking order theory, the more profitable companies have more internal resources, so they do not need external funding.

We suppose that the higher profitability is accompanied by a better credibility, and for this reason, our sample will be separated according to these variables, and their direction will be the same. So, in our second hypothesis, we claim that H2: in the industry with the higher profitability, the role of liabilities will be more significant regarding funding.

\section{Metodology}

\section{Data}

The research is based on the Orbis database of Bureau Van Dijk, which contains details about 110 million companies from 226 countries around the world. The screening was carried out on the basis of countries and areas of activity, selecting Hungary and France, with the 1102 grape wine production NACE code describing the wine production. Next, we divided the companies into separate tables 
according to countries, followed by the performance of the aggregation of the balance sheets and the financial indicators. In this way, we obtained the dataset concerning the individual countries and the values describing the whole branch. During the descriptive statistical analysis, we tried to take into consideration the greatest possible item number, as in this part, we aimed to describe the economy comprehensively. The number of the selected companies is 935 and 1498 for Hungary and France respectively, and this refers to those active companies that were part of the sector during the examined period. During the time-series analysis, we examined those indicators that are mentioned by the specialized literature as well in connection with the capital structure and profitability. We paid attention to the fact that the indicators can be derived from companies' financial statements, so they will show the book value. The examined time period is 10 years, which will present all the processes of the wine growing sector of the examined countries that can be described by the available financial indicators. The multivariate discriminant analysis culminates in the form of a process that categorizes the observation units into pre-defined classes according to multiple variables (Altman, 1968). Basically, there are two types of discriminant analysis: bivariate and multivariate. In the first case, there are two categories, while in the latter case, there are more categories of the dependent variable.

\section{Statistical analysis}

The regression equation resulting from the regression analysis is similar to the discriminant function, but in the case of the regression, the dependent variable is estimated. The discriminant analysis estimates whether or not an observation belongs to the given group. A strikingly common characteristic of the discriminant analysis and the cluster analysis is that in both cases, groups are concerned. The difference between these is that in the case of the discriminant analysis, the groups are given in advance, and the purpose of the analysis is to determine a linear combination of the dependent variables that separate the groups to the largest degree. In the case of the cluster analysis, the groups are not developed in advance, and the purpose of the analysis is to find the best method for the categorization of the cases into the groups (Sajtos - Mitev, 2006).

For the implementation of the analysis, we examined whether the following conditions are met: (i) The data do not correlate with each other.; (ii) All observations of the dependent variable belong exclusively to one group; (iii) The group sizes are the same; (iv) There is a linear relationship between the independent variables; and ( $v$ ) The normality was fulfilled; this was studied by means of the Kolmogorov-Smirnov test, which showed that this criterion was met.

By means of the Box's $M$ indicator, the congeniality of the covariance matrices has been stated. The alternative of the discriminant analysis is the logistic regression, which is more robust; however, the requirements of its use are less stringent. Accordingly, the run of the logistic regression analysis is recommended instead when there are some independent variables that are not metric, such as when the variance between the groups is not equal and the variables are not normally distributed.

We have chosen the discriminant analysis because in the database, there is only one grouping variable, which refers to the countries, and the other conditions relating to the analysis are also met. These will be examined in further detail.

The next step of the examination in order to verify the results of the discriminant analysis is the cluster analysis where we used the same variables that were involved during the first method. 
The number of companies involved in the analysis is good enough to launch a Kmeans clustering where the cluster numbers have to be determined in advance and from this reason a hierarchical cluster analysis was performed first. During this method the cluster membership depends on the distance between the item and the cluster center which has to be the smallest. After the classification the center of each cluster is being recalculated for each group and will be repeated till we find the appropriate centers where there is no need for further recalculations.

Determining the appropriate sample size in this research depends on the basis of rule of thumb .The number of the sample, i.e. the magnitude of companies within a country's border, needs to be set ten times more than the amount of independent variables. In line, the original sample size before clarification is maintained with a number of 50-50 companies from the overhauled countries. (Sajtos and Mitev, 2007)

\section{Results}

From 2007, the revenue of the Hungarian wine industry declined steadily until 2011. Then, in the following two years, the trend reversed, and the sector realized a significant increase. Although the current year's income in real terms is less than before the crisis, the value of 370 million EUR is 35\% higher than the figures from 2011 , which were the lowest point. This is mainly due to the increase in the number of market leader companies. A number of companies, have been founded in the last five years and have since become significant in the sector. In 2013, the revenue of the French wine industry was more than twenty times that of the Hungarian industry; however, apart from in 2014, the growth here is constant. While the value of the 8.27 billion EUR is 100 million EUR less than a year earlier, that is, 2012, it is higher both in nominal and in real terms than in 2008. The Hungarian wine industry cannot be considered to be concentrated. Half of the total revenue is concentrated in 12 companies; 106 firms provide $90 \%$ of the revenue. The proportions are similar in the French sector as well, with 250 companies making up $90 \%$.

In terms of profitability, the explanation is quite complex. The profit margin was the highest in 2006, but it had not reached the $5 \%$ level even then. The lowest points were in 2005 and 2012 when the indicator was less than 1\%. The sector improved in the current year; the value of the $2.88 \%$ is about average for the examined period. The French wine manufacturers are characterized by a higher profitability; even the indicator of the weakest year exceeds the best Hungarian values, and the shape of the curve is different. The low point in 2009 then the subsequent growth illustrates the drop caused by the economic crisis and then the recovery from it. In contrast, the indicator in Hungary after the initial co-movement decreased for three years after 2009. The return on assets and the return on equity developed in a similar way to the profit margin. The differences experienced in the case of the profit margin can be observed here as well, and it can be seen that the French sector surpasses the Hungarian one each year and the trends are the same. 
Figure 1

Profit margin in selected countries, 2004-2013

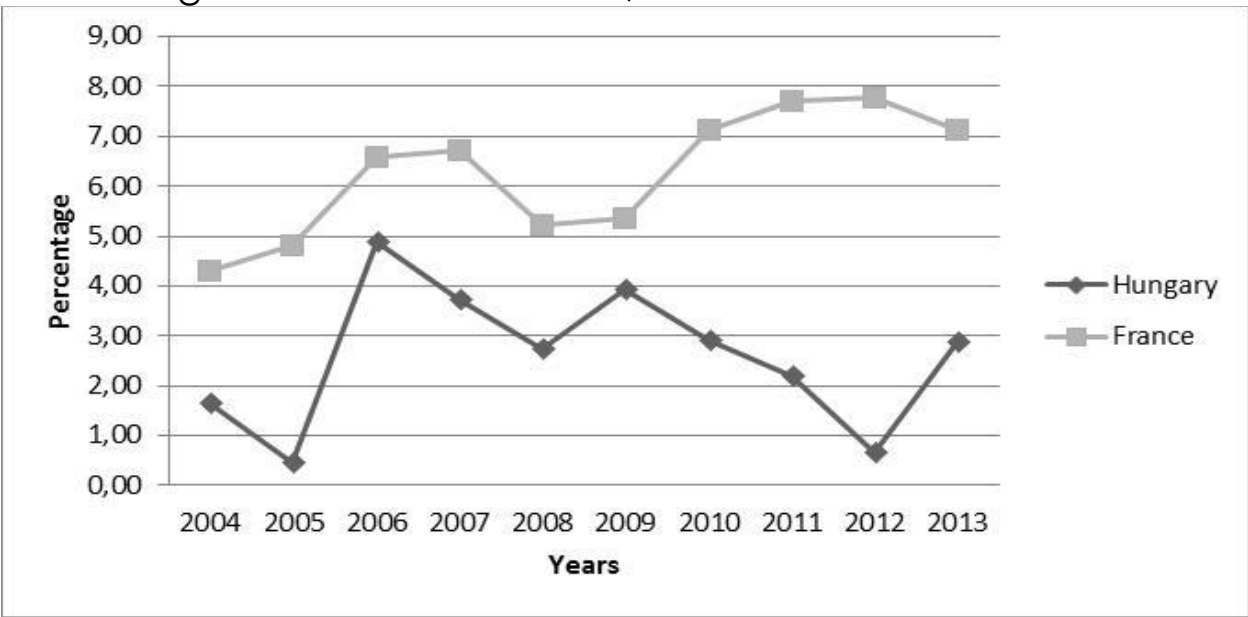

Source: Orbis

The proportion of the liabilities was under $50 \%$ within the liabilities and equities in the Hungarian wine growing industry each year. The low standard deviation (2.06) calculated from the indicators of the last 10 years indicates the balance which is valid in the case of the liabilities of two different terms. Throughout the examined period, the current liabilities were dominant; their average value is $30.9 \%$, and the standard deviation is 2.09. Similar to the proportion of the liabilities, there are no significant differences here, either. Only the year 2008 can be considered to be somewhat salient, as the proportion of the current liabilities was $35.9 \%$. The proportion of the non-current liabilities developed in a more interesting way; the average value is $15.6 \%$ the standard deviation is 1.9 , and we can see the highest value in nominal relation and in proportion in the current year as well, which has grown significantly during the last four years. Due to the constant ratio of the liabilities, this process meant a moderate shift towards the non-current liabilities in the branch.

Figure 2

The proportion of the current and non-current liabilities in the Hungarian wine producing sector

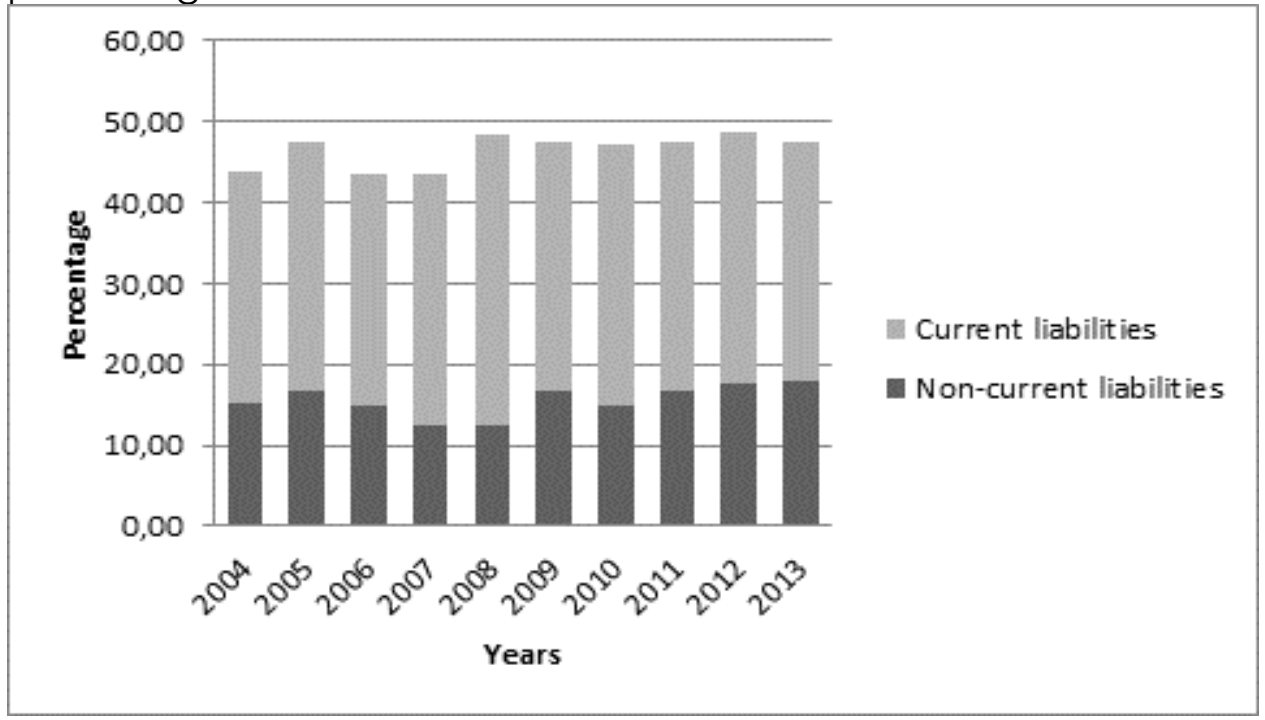

Source: Orbis 
A similar trend can be observed in the case of the long-term loans. In addition to the growth, it is remarkable that in four years, the number of companies in whose balance sheets the loan with the given term can be found has increased by 34 . In this context, the growth of the rate of the tangible fixed assets can be observed as well. By comparing the two graphs, it is clear that the two curves move virtually completely together. The local peak and the lowest points are the same everywhere. The proportion of the suppliers shows a decrease; the indicator moved between 16 and 17\% in recent years, while between 2007 and 2009, we can see successively a value of over $20 \%$.

Figure 3

The proportion of the non-current liabilities and the fixed assets in the Hungarian wine-growing industry

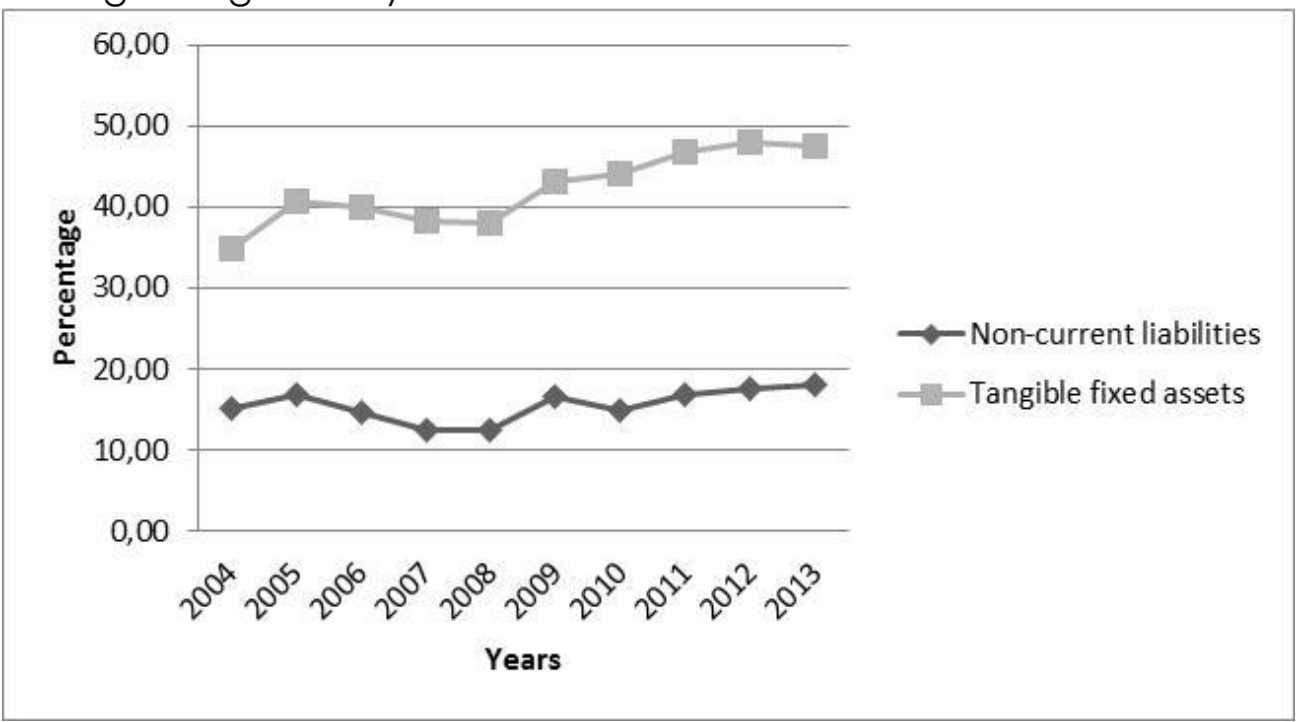

Source: Orbis

The proportion of the liabilities is more significant in the French enology which in contrast to the Hungarian, exceeds $50 \%$ each year. Before 2006 , it was constantly over $60 \%$. However, in the 10 years since 2004, a general decreasing trend can be observed as well, except for two years when the proportion of the liabilities was each year lower than in the previous year. Otherwise, the peak was in 2008, when the proportion of the liabilities was $65.4 \%$. The $54.2 \%$ of the current year is the lowest value of the examined period, considering its proportion the Hungarian level. The decrease in the proportion of the current liabilities, which has dropped from the initial $50 \%$ to $34.3 \%$, has played a significant role in this. In contrast, the non-current liabilities have come to the fore; their proportion reached $25 \%$ in 2009 . An increase in the given liability type can be observed until the aforementioned peak in 2009, and their proportion has been decreasing within the total liabilities in the current year until a value below $20 \%$ can be seen again. 
Figure 4

The proportion of the current and non-current liabilities in the French wine-producing sector

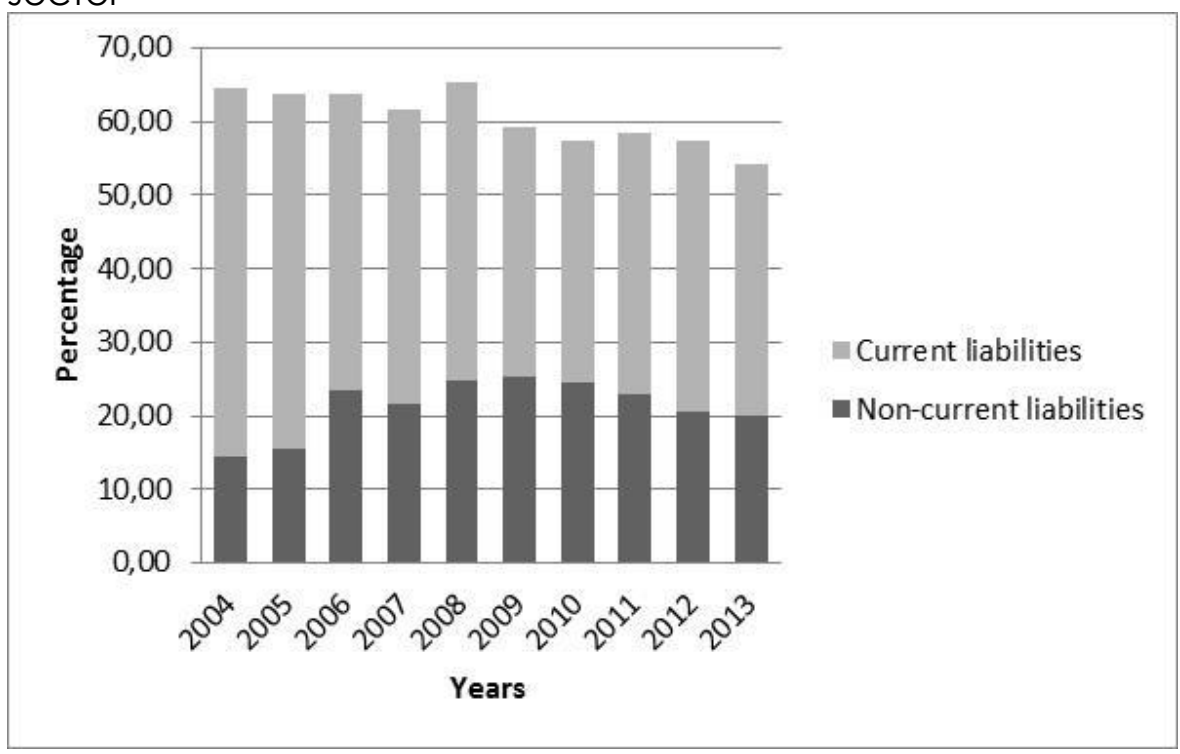

Source: Orbis

The ratio of the fixed assets shows a balanced picture in the last 10 years. Therefore, we could not find a similar correlation with the non-current liabilities, as is the case of the Hungarian sector. Due to the low proportion of fixed assets, we conclude that the proportions of the assets that can be involved as provision do not have such a significant role in lending in the Hungarian market. Furthermore, the current assets and, within this, the proportion of the stocks, plays a significant role in the composition of the assets. The indicator over the last five years was over $50 \%$ in the French sector, while in the Hungarian market, it did not reach $30 \%$. The ratio of the suppliers is much higher within the current liabilities in the French sector, where the indicator of $34.4 \%$ is more than double that of the Hungarian wine-growing industry. In general, it can be seen that the French sector applies the suppliers' credit in a higher proportion from the current liabilities than from the short-term loans. In the Hungarian sector, the opposite occurs.

Figure 5

The proportion of non-current liabilities and fixed assets in the French wine-growing sector

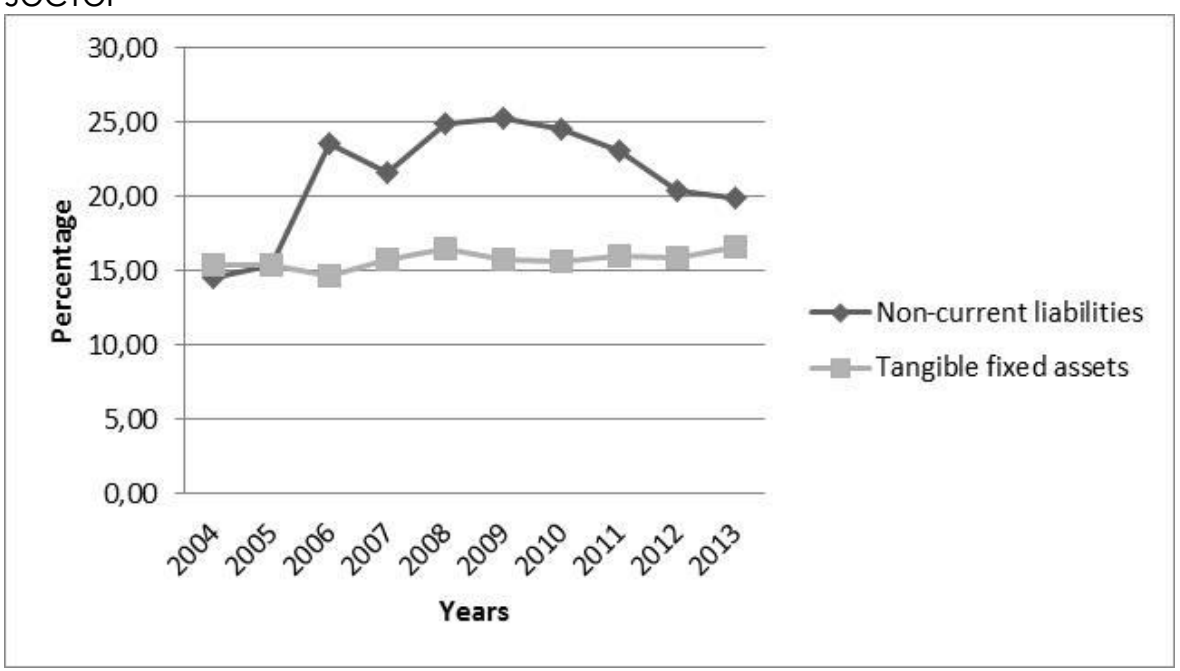

Source: Orbis 
Next, we examined the 50 Hungarian and French companies with the highest revenue by means of discriminant analysis. The aim of the analysis is to show all the variables that affect the discriminant function, that is, to separate the two groups from each other. Using a boxplot, the salient values were filtered out, so the sample finally comprised in total 40-40 enterprises in which $70 \%$ and the $60 \%$ of the 2013 revenue of the French and Hungarian sector respectively are concentrated.

The analysis was carried out by applying three different indicator-structures for the year 2013 so that the conditions would be met. The income situation and the solvency are presented by means of the ANOVA table:

Table 1

ANOVA table I.

\begin{tabular}{lrrrrr}
\hline & Wilks' Lambda & F & df1 & df2 & Sig. \\
\hline Return on Equity & 0.993 & 0.532 & 1 & 78 & 0.468 \\
Return on Assets & 0.994 & 0.456 & 1 & 78 & 0.501 \\
Profit\% & 0.989 & 0.875 & 1 & 78 & 0.352 \\
EBIT\% & 0.994 & 0.497 & 1 & 78 & 0.483 \\
Turnover/Total & 0.966 & 2.726 & 1 & 78 & 0.103 \\
Assets & & & & & \\
Liquidity ratio & 1.000 & 0.011 & 1 & 78 & 0.918 \\
\hline
\end{tabular}

Source: Orbis

In Table 1, it is worth noting the Wilk's Lambda indicator and the significant level related to the single indicators. The Lambda value related to the $F$ test shows the extent to which the independent variable contributes to both the discriminant line and the discriminant function. The indicator can take the values between 0 and 1; the smaller it is, the more significant its effect is on the function. By means of the significant levels and the related Lambda value, it can be concluded that the countries are not separated by these indicators. However, it would be worthwhile examining which country performs better regarding the year 2013 (Table 2).

Table 2

The group statistics

\begin{tabular}{llcc}
\hline & & Average & Standard Deviation \\
\hline Hungarian & Return on Equity & 9.460 & 16.061 \\
& Return on Assets & 3.710 & 5.506 \\
& Profit\% & 4.088 & 9.756 \\
& EBIT\% & 5.546 & 9.732 \\
& Liquidity ratio & 0.675 & 0.428 \\
& Turnover/Total Assets & 78.765 & 49.478 \\
\hline French & Return on Equity & 7.415 & 7.510 \\
& Return on Assets & 3.042 & 2.967 \\
& Profit\% & 5.804 & 6.285 \\
& EBIT\% & 6.879 & 6.944 \\
& Liquidity ratio & 0.666 & 0.349 \\
& Turnover/Total Assets & 63.552 & 30.793 \\
\hline
\end{tabular}

Source: Orbis

According to the averages, the profitability of the Hungarian sector proved to be better when based on the assets and on the proportional indicator of the shareholders' fund, but the high standard deviation indicates significant differences 
between the performances of the single companies. Compared to the aggregate indicators of the examined 40 companies we obtain a much lower value (5.3 respectively 2.7). However, in the French sector, the opposite is the case: the aggregate values show a significantly higher value (12.5 respectively 4,9$)$, which can be explained by the performance of the companies with a dominant market share. These differences appeared in the case of the other indicators as well, so it is ascertainable that the profitability indicators of the sampled companies that have the greatest revenue by countries show significant differences compared to both the average gained from them and to the aggregate values. This difference is more significant in the case of the Hungarian sector.

In the case of the second run, we examined the impact on the discriminant line of the tax effect and of the proportion of the current and non-current liabilities, which will be shown again by the ANOVA table (Table 3.):

Table 3

ANOVA table ॥

\begin{tabular}{lrrrrr}
\hline & Wilks' Lambda & F & df1 & df2 & Sig. \\
\hline $\begin{array}{l}\text { Tax effect } \\
\begin{array}{l}\text { Proportion of the non-current } \\
\text { liabilities }\end{array}\end{array}$ & 0.995 & 0.407 & 1 & 78 & 0.525 \\
Proportion of the current liabilities & 0.963 & 3.024 & 1 & 78 & 0.086 \\
\hline
\end{tabular}

Source: Orbis

As can be seen from the second ANOVA table, the proportion of the non-current liabilities of the three indicators could be accepted at most in the case of a $10 \%$ significance. The remaining two significant levels - related to the F-test - are too high. However, it is useful to examine this at an average level to provide a comparison of the two countries (see Table 4)

Table 4

Group statistics II

\begin{tabular}{llcc}
\hline & Average & Standard Deviation \\
\hline Hungarian & Proportion of non-current liabilities & 11,197 & 11,967 \\
& Proportion of current liabilities & 36,054 & 16,388 \\
& Tax effect & 7,382 & 14,270 \\
\hline \multirow{2}{*}{ French } & Proportion of non-Current liabilities & 17,374 & 19,010 \\
& Proportion of current liabilities & 42,160 & 17,243 \\
& Tax effect & 12,432 & 47,963 \\
\hline
\end{tabular}

Source: Orbis

Based on this, the external financing in the case of the French can be considered to be much more a majority financial form both among those within the year and among those over the year. However, the dispersion declares that the rate of utilization of the resources is much more diversified in the case of the French. Examining the tax effect at an average level, it is ascertainable that the French perform a tax liability of a greater volume. However, it should be noted that the rate of the French income tax is $33 \%$, which is more than double the Hungarian rate of $16 \%$ (http://hu.tradingeconomics.com/france/corporate-tax-rate).

By the third execution, the variables that were analyzed were those that actually affected the discriminant function. The third ANOVA table shows this: 
Table 5

ANOVA table III

\begin{tabular}{lcrrrrr}
\hline & Wilks' Lambda & F & df1 & df2 & \multicolumn{1}{c}{ Sig. } \\
\hline $\begin{array}{l}\text { Proportion of the fixed } \\
\text { assets }\end{array}$ & 0.707 & 32.277 & 1 & 78 & 0.000 \\
$\begin{array}{l}\text { Proportion of the } \\
\text { equity }\end{array}$ & 0.889 & 9.750 & 1 & 78 & 0.003 \\
$\begin{array}{l}\text { Export earnings } \\
\text { against the revenue }\end{array}$ & 0.952 & 3.962 & 1 & 78 & 0.050 \\
\hline \begin{tabular}{l} 
Net working capital \\
\hline
\end{tabular} & 0.933 & 5.565 & 1 & 78 & 0.021 \\
\hline
\end{tabular}

Source: Orbis

Table 5 shows us that all four variables affect the discriminant function significantly, and the Lambda value relating to them is lower than was shown previously in the other cases.

Table 6

Correlation of the centers and the variables

\begin{tabular}{llll}
\hline & & \\
Country & Function & Business-related variables & Function \\
\hline Hungarian & 0,734 & Proportion of the fixed assets & 0.866 \\
\hline French & $-0,734$ & Proportion of the equity & 0.476 \\
\hline & & Net working capital & -0.360 \\
\cline { 3 - 4 } & & Export earnings against the revenue & -0.303 \\
\cline { 3 - 4 } & & &
\end{tabular}

Source: Orbis

Table 6 shows that the rate of the fixed assets represents a more significant proportion in the Hungarian sector in the examined year, in the sample that comprises 40-40 companies. The proportion of the fixed assets can be considered as indicating a considerable assets portfolio in many instances, especially in the cases of those companies where external financing is preferred with the existence of different asset coverage. Returning to the previous companies, it can be concluded that the proportion of the loans is higher for the French, but also the rate of the fixed assets is lower there. This can be explained by the high proportion of unsecured liabilities.

The rate of equity is higher in the financing by the Hungarian enterprises, which is supported by the fact that the proportion of the various current and non-current liabilities is lower. Based on this, it is ascertainable that the French actually prefer the external resources, primarily the short-term ones, due to the lower interest rates. In the case of financing, it can be assumed that the Hungarian companies follow a less aggressive financing policy, but let us examine the value of the net working capital. The index can be calculated as the difference of the temporary assets and the temporary liabilities. If we declare that the difference is lower for the domestic companies, it is still not certain that this means there is a more aggressive strategy in the financing. It is worth paying attention to the members, in particular to which is greater and which smaller with respect to the two countries. The transitional/current assets play a more significant role in French, while in the case of the current liabilities, the same is true, but regarding the liabilities. Should the connection not have been one-way, but for instance, in the case of the Hungarian wine industry, the proportion 
of the current liabilities would be more significant, then it would be obvious that the smaller value of the net working capital results from this.

In order to verify the results of the discriminant analysis we launched a cluster analysis and examined which variables will lead us to the same cluster size where the variables will also have a significant effect. After several attempts we found a three variable model which could fulfil our previously set requirements so the number of companies in the two clusters is nearly the same. The variables which determined the 2 clusters are the following:

- Liabilities/Total Assets

- Non-current Liabilities/Total Assets

- Fixed Assets/Total Assets

- Export Revenue/Turnover

Out of these 4 ratios, two of them also played a role in the discriminant analysis.

In the bigger cluster there are 43 companies out of the 80 and most of them exactly $70 \%$ - are part of the Hungarian wine industry which is displayed by the country variable where the average is 1,30 . Since we used dummies and named the Hungarian companies with 1 and the French's with 2 so it is clear what this value tries to indicate. This group dominated by the Hungarian wine manufactures has higher level of fixed assets (Median 38.84) which confirms both the results of the discriminant analysis and the descriptive analysis. We have the same observation in case of the debt ratio, the 45.49 Median value is close to the total market average that we have experienced on the Hungarian market. The ratio related to the non-current liabilities was not in the discriminant analysis and also did not show a big difference when we examined the total market but in this mixed group it proved to be a segregate variable.

In the second cluster where the number of companies was bit lower, 37 out of the 80 the proportion of fixed assets reflects the Assets structure of the French companies where this low value (Median 17.45) was typical and was on the same level in case of the total sample. French companies are highly dominating this cluster, 73 percent of the companies belongs to the French market. The debt ratio is also very high here compared to the first group, the 70.22 Median and 67.24 Average is a bit higher than in the two other analysis but the direction confirms the previous consequences i.e. the proportion of liabilities is higher in case of the French companies. The level of non-current liabilities shows a significant difference compared to the other cluster, this appeared only in the group statistics of the sample used for the discriminant analysis. The 4th variable was the Export revenue/Turnover which has a higher value in the French dominated cluster.

We also examined which variables have the most significant discriminating effect or in other words according to which variables do the two cluster differs from each other. We included an ANOVA table where the $F$ value helps us to create this ranking. The higher is the value, the more determinant role has the variable distinguishing the two clusters. In our case the proportion of liabilities was the most decisive than comes the long term liabilities/total liabilities ratio and at the end stays the proportion of fixed assets. In all three cases the $\mathrm{F}$ value proved to be significant so they have a discriminating effect on the clusters. 
Table 7

Case summaries

\begin{tabular}{llrrrr}
\hline \multicolumn{2}{c}{ Cluster Number of Case } & $\begin{array}{c}\text { Fixed Assets } \\
\text { /Total Assets }\end{array}$ & $\begin{array}{c}\text { Liabilities } \\
\text { /Total Assets }\end{array}$ & $\begin{array}{c}\text { Non-current } \\
\text { Liabilities } \\
\text { /Total Assets }\end{array}$ & $\begin{array}{c}\text { Export } \\
\text { Revenue } \\
\text { /Turnover }\end{array}$ \\
\hline \multirow{2}{*}{ Cluser 1 } & $\mathbf{N}$ & 37 & 37 & 37 & 37 \\
\cline { 2 - 6 } & Mean & 18.385 & 67.240 & 22.364 & 19.770 \\
\cline { 2 - 6 } & Median & 17.450 & 70.230 & 19.150 & 14.000 \\
\cline { 2 - 6 } & Std. Error of Mean & 1.715 & 1.906 & 3.132 & 3.253 \\
\hline Cluster 2 & $\mathbf{N}$ & 43 & 43 & 43 & 43 \\
\cline { 2 - 6 } & Mean & 38.844 & 42.104 & 7.150 & 6.160 \\
\cline { 2 - 6 } & Median & 38.620 & 45.490 & 5.830 & 0.000 \\
\hline \multirow{2}{*}{ Total } & Std. Error of Mean & 2.883 & 2.006 & 1.013 & 1.848 \\
\cline { 2 - 6 } & $\mathbf{N}$ & 80 & 80 & 80 & 80 \\
\cline { 2 - 6 } & Mean & 29.380 & 53.729 & 14.187 & 12.450 \\
\cline { 2 - 6 } & Median & 23.780 & 52.865 & 8.800 & 3.000 \\
\cline { 2 - 6 } & Std. Error of Mean & 2.077 & 1.976 & 1.757 & 1.947 \\
\hline
\end{tabular}

Source: Orbis

Table 8

Anova analysis for the clusters variables

\begin{tabular}{|c|c|c|c|c|c|c|}
\hline & \multicolumn{2}{|c|}{ Cluster } & \multicolumn{2}{|l|}{ Error } & \multirow[b]{2}{*}{$\mathbf{F}$} & \multirow[b]{2}{*}{ Sig. } \\
\hline & $\begin{array}{l}\text { Mean } \\
\text { Square }\end{array}$ & df & Mean Square & df & & \\
\hline Fixed Assets/Total Assets & 8328,484 & 1 & 242.853 & 78 & 34.294 & 0.000 \\
\hline Liabilities/Total Assets & 12565,142 & 1 & 155.294 & 78 & 80.912 & 0.000 \\
\hline $\begin{array}{l}\text { Non-current } \\
\text { Liabilities/Total Assets }\end{array}$ & 4603,518 & 1 & 191.304 & 78 & 24.064 & 0.000 \\
\hline $\begin{array}{l}\text { Export } \\
\text { Revenue/Turnover }\end{array}$ & 3685,542 & 1 & 259.803 & 78 & 14.186 & 0.000 \\
\hline
\end{tabular}

Source: Orbis

\section{Conclusions}

The national culture of the wine industry in France is totally supported by the given financial indicators. It is clear that the French wine industry's total revenue is twenty times greater than that of Hungary at an aggregate level, and its profitability is significantly higher. Although important issues need to be clarified, the French market is expected to receive more in exports, and there are differences in the number of companies. Discriminant analysis offers a similar result. This method also reveals that regarding profitability, the Hungarian companies have a higher level of effectiveness compared to the French, although a higher standard deviation can be seen on descriptive statistics, which means simultaneously greater differences and shifts compared to the average in the smooth operation of companies. Nevertheless, it raises the possibility of an increase in effectiveness globally.

In the case of capital structure, the rate of external capital is higher in France, but only for the short-term financing. The long-term resource of financing at a $10 \%$ level of significance is a discriminant factor, which maintains the majority of the source utilized by the French industry. The reputation, the quality, and the market position of French wine determine the higher effectiveness at an aggregate level in order to make France's companies more eligible for credit, because the EBITDA can provide 
a higher portion as payments for debt service. Based on that fact, the first hypothesis is proved empirically. The analysis reveals that the rate of tangible assets is completely in line with the external financing sources in the specified period. As a possible consequence of this, the regulation of coverage requirement is stricter in the Hungarian region. In contrast, it needs to be recognized that the French historical operation may reveal distortion about the passage of time regarding the accounting policy utilized for amortization. While the fact may not be well established, the liquidity position of the examined countries is similar, which is the underlying point in debt capacity in a timely manner. This problem can serve as a basis for further research regarding the financing strategy, because the ratios are significantly lower than could be expected for either, and the net working capital cannot ascertain the exact financing strategy properly. Most of the short-term financing resources are in the form of trade creditors in the French companies, whereas in the Hungarian companies it is at least double the rate of the source. The source is preferable because of its low level of expense in such financing links and because of the possibility of being supplied at a zero rate of interest. The capital structure via discriminant analysis is different in the point of equity rate at a $5 \%$ significance level, which demonstrates that internal sources are preferable in the Hungarian region; the graphs support the volatility of external sources for financing. Nevertheless, it can be observed that the equity of the Hungarian companies increased variably by the relevant net profit from the year 2004. Because of this, the second hypothesis is assumed to be true empirically.

The coverage of tangible assets, the equity rate, and the observed difference via discriminant analysis regarding the effectiveness indicate a prosperous line for future development in part due to the creditworthiness of the companies, although the profitability and the possible performance of the future cannot be guaranteed. Currently, the sector is being subsidized by government programs. However, it is expected that not only do the money and capital markets need to be developed, but simultaneously, the internal processes of the companies need to be evolved. There can be in the long-term sources, not including that of long-term working capital loans, a difference in respect of investments at a national level. It would be worth taking into consideration that the owned equity is subject to a high interest rate, so Hungary needs to turn to the cheaper short-term external sources or have more adequate investments that have the appropriate level of self-effort in regard to the capacity of the market being supplied. The coverage attests to the possibility of finance being provided by financial institutions explicitly. Nevertheless, differences have emerged in the solvency demand at a national level. The enhancement of the internal and the external market through the monetary easing to revive the economy may affect the profitability of the companies sufficiently.

The performance of the Hungarian wine-growing sector can be considered as having been stable in recent years; the growth in income has exceeded inflation constantly which is mainly due to the expansion of the market actors over the last five years. In this respect, the French sector acts in a similar way as well, and based on that, it can be ascertained that the prospects of the industry are more positive compared to a few years ago. In terms of profitability and efficiency, the French wine-production industry is ahead of the Hungarian one, which creates a more favourable position with regard to further growth.

The role of the liabilities in the financing is moderate in the case of both countries; examination of the trends shows they converge slightly, but it is still higher in the French sector. The proportion of the non-current liabilities moves in accordance with the rate of the fixed assets in the Hungarian sector, so it can be seen that the 
financing is closely related to the existence of the assets that serve as funds. This is not true for the French sector, where the prevalence of the current assets is dominant. The discriminant analysis revealed that the two sectors differ from each other based on the proportion of the shareholders' funds, the rate of the fixed assets, the export ratio, and the net working capital. That partly supports the findings of the time series analysis and highlights new variables that should be examined.

\section{References}

1. Altman, E. I. (1968): Financial ratios, discriminant analysis and the prediction of corporate bankruptcy. The Journal of Finance. 23. évf. 4. sz. 589-609. old.

2. Borszéki É. (2008): Vállalati pénzügyek, Szent István Egyetemi Kiadó, Gödöllő

3. Brealey - Myers (1999): Modern vállalati pénzügyek, Panem Kft., Budapest

4. Donaldson, G. 1961. Corporate Debt Capacity: A Study of Corporate Debt policy and the Determinants of Corporate Debt Capacity. Harvard Business School, Division of Research, Harvard University.

5. Gill, A., Biger, N., Mathur, N. (2011): The Effect of Capital Structure on Profitability: Evidence from the United States International Journal of Management Vol 28, No 4. 3-15.

6. Jensen, M. C., \& Meckling, W. H. (1976). Theory of the Firm: Managerial Behavior, Agency Costs and Ownership Structure. Journal of Financial Economics, Vol. 3, 305-360.

7. Modigliani, F. and Miller, M. H., 1963. Corporate income taxes and the cost of capital: a correction. The American Economic Review, 53, 2, 433-443.

8. Myers, S.C. and Majluf, N.S., 1984. Corporate financing and investment decisions when firms have information that investors do not have. Journal of Financial Economics, 13, 187-221.

9. Psillaki M., Margaritis D.(2009): Capital Structure, Equity Ownership and Firm Performance, Greece Journal of Banking \& Finance 03/2010, 34:621-632

10. Psillaki M.,Daskalakis N. (2008): Are the Determinants of Capital Structure Country or Firm Specific? Evidence from SMEs, Small Business Economics, Vol. 33, No. 3, pp. 319-333

11. Sajtos L. - Mitev A. (2007): SPSS kutatási és adatelemzési kézikönyv, 2007, Alenia Kiadó, Budapest.

12. Stiglitz, J., 1972. Some aspects of the pure theory of corporate finance: bankruptcies and take-overs. Bell Journal of Economics and Management Science. 3, 458-482.

13. Székelyi M., Barna I. (2002): Túlélőkészlet az SPSS-hez, Typotex Kiadó, Budapes†

14. Szűcs I. (2002): Alkalmazott statisztika, Agroinform Kiadó, Budapest

15. Viviani, J.-L. (2008). Capital Structure Determinants: An Empirical Study of French Companies in the Wine Industry. International Journal of Wine Business Research, Vol. 20 Issue 2, 171 - 194.

16. Xu, J. (2012): Profitability and capital structure: Evidence from import penetration, Volume 106, Issue 2, 427-446. 


\section{About the authors}

Martin Luptak works for Bureau Van Dijk since 2007. Currently he is working as Central and Eastern Europe Key Account Manager. He is responsible for developing Compliance, Transfer Pricing, Credit risk markets in the region and managing the South sales team. Martin started his career in 2003 as Fundraising manager at Greenpeace right After finishing the Political science and International Relations faculty in Banska Bystrica. Author can be contacted at martin.luptak@bvdinfo.com

Daniel Boda graduated as an economist at Szent Istvan University-Gödöllő with a specialization in corporate finance. His main interest better and better turned to quantitative disciplines such statistics, and mathematical-statistics. With a special focus on the previous, he started studying for holding a PhD at the same university majored in finance. Research fields are the following: probability of default, regional differences using multivariate statistical methods. Author can be contacted at bodadaniel1990@gmail.com

Gabor Szucs is a managing director of Creditreform Hungary, previously he worked in the market research industry. He graduated at the Corvinus University Budapest at the faculty of sociology and economics than on the Budapest Business School at the faculty of Risk Management. He started his Ph.D. studies last year on the field of capital structure and corporate finance. Being involved in several international projects within the Creditreform group, from 2015 January he also holds the position Sales and Marketing Director at AM Holding, owner of 6 Creditreform offices worldwide. Author can be contacted at g.szucsi@gmail.com 